\title{
Kompletterende sykepleierutdanning gir verdig vei mot autorisasjon
}

Sykepleiere utdannet i land utenfor EU er en viktig ressurs for norsk helsevesen, og det er stort behov for deres kompetanse.

\section{Forfattere}

\author{
Kari Dahl \\ Førstelektor \\ Oslomet - storbyuniversitetet

\section{Line Nortvedt} \\ Førsteamanuensis \\ Oslomet - storbyuniversitetet

\section{Cindy Balane Ligan} \\ Student \\ Oslomet - storbyuniversitetet
}

\section{Nøkkelord}

Kultur Utdanning Undervisning

Sykepleien 2018 106(69584)(e-69584)

DOI: https://doi.org/10.4220/Sykepleiens.2018.69584

\section{HOVEDBUDSKAP}

Artikkelen omhandler bakgrunn for og erfaringer knyttet til kompletterende utdanning for sykepleiere utdannet utenfor EU og beskriver den formelle og opplevde veien til autorisasjon som sykepleier i Norge. Veien til autorisasjon synes komplisert, urettferdig og uforutsigbar, og det er et stort behov for et bedre system.

Den kompletterende utdanningen stiller nødvendige sykepleiefaglige krav, som sikrer både kvalitet i møte med det norske helsevesenet og en verdig og forutsigbar vei for sykepleiere.

Ifølge Nova hadde Norge en mangel på 2350 sykepleiere og 200 spesialsykepleiere i 2015 (1). SSB har beregnet at vi vil få et underskudd på 28000 sykepleiere i 2035 (2).

I 2014 var det cirka 100000 sykepleiere i arbeid i Norge. Av disse var 4124 utdannet jordmor, sykepleier eller helsesøster fra et land utenfor EU (bortsett fra USA, Canada, Australia og New Zealand) (3). Det er viktig å presisere at Norge har forpliktet seg til, gjennom avtaler $(4,5)$, ikke å rekruttere helsepersonell fra land som mangler dette.

\section{Alle skal delta}


Norge bør bli bedre på å ta i bruk og utnytte innvandreres kompetanse (6).

Alle som bor i Norge, skal, ifølge Barne- og inkluderingsdepartementet, gis mulighet til å delta i arbeids- og samfunnsliv. Arbeid er nøkkelen til økonomisk selvstendighet, samfunnsdeltakelse og likestilling $(7,8)$.

Det viser seg imidlertid at migrerte sykepleieres kompetanse i liten grad blir utnyttet, fordi veien til autorisasjon er både uforutsigbar, komplisert og ressurskrevende for den enkelte. Kompletterende utdanning for sykepleiere med utdanning fra land utenfor EU/EØS (forkortet SKOMP) er et viktig bidrag for å utnytte kompetansen mer effektivt.

\section{Fortelling}

SKOMP-studentene ble spurt om å skrive en fortelling om veien til autorisasjon i Norge. Fortellingen under er trukket ut blant mange gode bidrag, og gir et innblikk i den migrerte sykepleierens perspektiv:

«Det å være sykepleier er jeg meget stolt av, og utdanningen på Filippinene var strevsom. Det var helt klart for meg at jeg ønsket å flytte utenlands, enten til Island eller Norge. Men da jeg kom til Norge alene i 2012, fikk jeg beskjed om at jeg ikke kunne være sykepleier, og jeg visste heller ikke hvordan helsesektoren fungerte her.

Jeg bodde med en som min tante kjente, og strevde de første seks månedene både økonomisk og psykisk. Jeg hadde ikke jobb, og jeg var vant til å jobbe.

Jeg hadde stort press på meg fordi familien min hadde det så dårlig på Filippinene. Mine foreldre var syke, og mine seks søsken gikk på skolen, så jeg hadde mange forskjellige jobber, som renholdsarbeider og servitør, for å sende penger hjem.

Jeg fikk min helsefagarbeiderautorisasjon etter sju måneder i Norge, og måtte skaffe meg en 80-100 prosent stilling, slik at jeg kunne fortsette å oppholde meg lovlig her. Da søkte jeg på et sykehjem og fikk en nattevaktstilling der.

Men drømmen og ønsket mitt var ikke oppfylt. Jeg var veldig opptatt av å få autorisasjon som sykepleier, og søkte Helsedirektoratet vinteren 2014. Jeg fikk avslag med vedtak om å starte sykepleierutdanningen på nytt. Det aksepterte jeg ikke. Hvordan skulle dette gå når faren min var alvorlig syk og jeg ikke kunne støtte familien?

Jeg søkte på nytt i 2015 og fikk avslag med vedtak om at jeg manglet 1000 timer teori og 1000 timer praksis. Dette skjønte jeg ikke helt.

Sommeren 2016 fikk jeg plass ved Universitetet i Oslo for å gjennomføre norskopplæring, men kunne ikke ta eksamen fordi pappa døde under eksamenstiden. Fikk tatt eksamen i desember og lyktes.

I januar 2017 søkte jeg for tredje gang, og fikk vedtak om å søke via Samordna opptak eller å ta Kompletterende utdanning for sykepleiere, og fikk plass begge steder. 
Og her er jeg som sykepleierstudent, og opplever at vi alle sammen i klassen er Norges fremtid.»

\section{Veien til autorisasjon}

Fortellingen viser at migrerte sykepleiere som er utdannet fra land utenfor EU, møter ulike og til dels kompliserte myndighetskrav når de kommer til Norge.

Helsepersonelloven (9) stiller følgende krav til utenlandsk utdannet helsepersonell i kapittel 9 § 48 a:

«Rett til autorisasjon etter søknad har den som

a) har bestått eksamen i vedkommende fag ved norsk universitet, høgskole eller videregående opplæring,

b) har bestått utenlandsk eksamen som er anerkjent etter avtale om gjensidig godkjenning etter $\S 52$,

c) har gjennomført utdanning og bestått utenlandsk eksamen som anerkjennes som jevngod med tilsvarende norsk utdanning og eksamen, eller

d) har godtgjort å ha den nødvendige kyndighet ved bestått eksamen i helsefaglig utdanning, og tilleggsutdanning eller yrkeserfaring.»

Ulike studier og rapporter viser at det er utfordringer knyttet til autorisasjon (10-12). Det er i første omgang Nasjonalt organ for kvalitet i utdanningen (Nokut) som vurderer omfang og nivå på utenlandsk høyere utdanning. For eksempel vil en bachelorgrad i sykepleie på Filippinene godkjennes som kun to år.

\section{Jevngodhet}

Neste steg er å søke Helsedirektoratet, som er autorisasjonsmyndighet for alt helsepersonell. Det er Helsedirektoratet som vurderer sykepleierutdanningens jevngodhet og kyndighet ved å sammenlikne søkers utdanning med norsk rammeplan for sykepleierutdanning (14).

De som blir vurdert som ikke jevngode, får avslag. Avslaget kan være endelig fordi utdanningen for eksempel er på et videregående nivå, og en får i stedet autorisasjon som helsefagarbeider.

Avslaget kan videre gi forslag om å søke gjennom Samordna opptak til en høyskole eller et universitet og be om fritak fra fag en har gjennomført, eller å gjennomføre et kvalifiseringsløp. Ingen får, så vidt vites, direkte autorisasjon når en har en sykepleierutdanning fra et land utenfor EU.

\section{«Avslaget kan gi forslag om å søke gjennom Samordna opptak til en høyskole eller et universitet.»}

Ulike vedtak i Helsedirektoratet kan forstås ut fra endringer i utdanningen i det landet sykepleieren kommer fra, samt endringer i vurderingene som blir gjort i Norge. For eksempel har Serbia endret sitt utdanningsprogram for å tilpasse seg utdanningssystemene i EU.

Et eksempel på endringer i Norge er overgangen fra å telle og sammenlikne timer til å telle og sammenlikne studiepoeng i teori, eller forskriftsendringer i helsepersonelloven ved innføring av språkkrav og fagprøve. 


\section{Tilleggskrav}

Krav til praksis er tydelig beskrevet i rammeplan for norsk sykepleierutdanning og er i tråd med EU-direktivene. Australsk sykepleierutdanning har eksempelvis ikke tre veiledede praksisperioder over seks uker, slik rammeplan for norsk sykepleierutdanning krever. Konsekvensen vil da kunne være et kvalifiseringsløp knyttet til praksis før en er vurdert som jevngod.

Et annet kvalifiseringsløp er kompletterende utdanning for sykepleiere, slik Oslomet har utviklet. Når en sykepleier er vurdert som jevngod etter kvalifiseringsløpet, må han eller hun i dag gjennomføre tilleggskrav for autorisasjon. Kravet er knyttet til språk, fagprøve, legemiddelhåndtering og kurs i nasjonale fag. Helsedirektoratet kan frita fra tilleggskrav.

Den formelle veien kan illustreres på følgende måte:

\section{Figur 1: Veien mot autorisasjon}

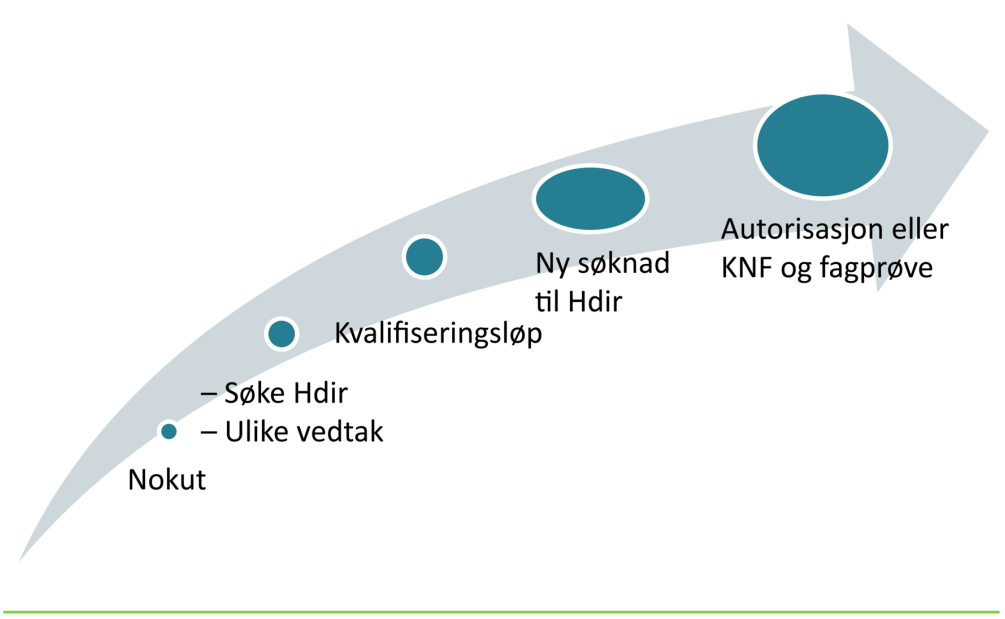

\section{Sammenlikning}

Kompletterende utdanning er tilpasset personer som allerede har fullført en utdanning i utlandet, men som trenger et tillegg for å få autorisasjon eller bli godkjent for yrkesutøvelse i Norge.

Forfatterne av denne artikkelen har vært med i et prosjekt finansiert av Kunnskapsdepartementet for å utvikle kompletterende utdanning for sykepleiere med fluktbakgrunn. Vi har vurdert ulike sykepleierutdanninger fra land utenfor EU og sammenliknet dem med norsk sykepleierutdanning.

Vurderingene av de utenlandske utdanningene tar utgangspunkt i programplaner og vitnemål fra ulike utdanningsinstitusjoner og blir sammenliknet med rammeplanen for den norske sykepleierutdanningen.

Utdanning fra Afghanistan, Bosnia-Hercegovina, Eritrea, Etiopia, Iran, Irak, Russland, Serbia og Syria har blitt gjennomgått i prosjektet. I tillegg har utdanning fra Australia, Bangladesh, Cuba, Filippinene, India, Japan, Kina, Makedonia, Nepal, Pakistan, Ukraina og USA blitt vurdert i sammenheng med faglige råd til Helsedirektoratet og i saker hvor studenter ved høyskolen ber om fritak på bakgrunn av egen utdanning. 
Det må understrekes at det er forskjeller mellom ulike utdanninger i samme land, og det vil alltid måtte gjøres en individuell vurdering av hver utdanning. Noen av utdanningene vi har gjennomgått, har ikke vært på riktig nivå sammenliknet med norsk sykepleierutdanning.

\section{Emnesammensetning}

Av teoretiske temaer som utpeker seg til å komplettere, er sykepleiens faglige og vitenskapelige grunnlag og sykepleiens samfunnsvitenskapelige grunnlag. Når det gjelder praksisemnene, er det spesielt psykisk helse og eldreomsorg som utpeker seg som områder for kompletterende utdanning.

Dagens kompletterende utdanning ved Oslomet består av fire emner med til sammen 60 studiepoeng, ved siden av legemiddelhåndtering, som har ett studiepoeng:

- sykepleiens faglige og samfunnsvitenskapelige grunnlag (15 studiepoeng)

- kliniske studier i eldreomsorg og geriatri (15 studiepoeng)

- kliniske studier ved psykisk og rusrelaterte lidelser (15 studiepoeng)

- bacheloroppgaven (15 studiepoeng)

Tre av emnene gjennomføres sammen med de ordinære bachelorstudentene, mens to emner er spesielt tilpasset sykepleiere utdannet utenfor EU.

Opptakskravet for å starte på studiet er vedtak fra Helsedirektoratet etter 1. juni 2015 og oppfylt krav til norsk og engelsk i henhold til forskrift om opptak til høyere utdanning.

\section{Første kull}

Det kompletterende studiet med 16 studenter fra henholdsvis Nepal, India og Filippinene startet høsten 2017. Studentene hadde bodd i Norge i i gjennomsnitt fem år. En var født og oppvokst her, men hadde tatt utdanningen sin på Filippinene.

Kun en av studentene oppga å ikke jobbe ved siden av fulltidsstudiet, mens alle de andre jobbet 25-100 prosent ved siden av. Prosentandelen endret seg da de startet i praksis.

SKOMP-studiet ble innledet med en åtte ukers teoriblokk. Temaer som ble gjennomgått, var sykepleiens grunnlagstenkning, etikk, helselovgivning, organisering av norsk helsevesen, kulturforståelse, kunnskapsbasert praksis og veiledningsteori, med en påfølgende skriftlig skoleeksamen den niende uken.

\section{Evaluering}

Mot slutten av teoribolken ble studentene bedt om å evaluere det de hadde erfart så langt i studiet. Med bakgrunn i muntlige svar i plenum, samt skriftlige individuelle tilbakemeldinger fra utdelte spørreskjemaer, kan vi si noe om studentenes perspektiv.

Det viste seg at 85,7 prosent av studentene var svært fornøyde med studiet etter åtte uker, 14,3 prosent var fornøyde, mens ingen var misfornøyde.

\section{三 «Å veilede førsteårs sykepleierstudenter på simuleringsenheten var noe av det mest lærerike.»}


Den pedagogiske tilnærmingen var fordelt på forelesninger, workshops, seminarer og studieoppgaver. Studentene var i all hovedsak svært fornøyde med forelesninger, viste seg å ha stort engasjement i gruppearbeid og rollespill, men evaluerte antallet studieoppgaver negativt (for tett mellom de første studieoppgavene).

De sa videre at databasesøk, kunnskapsbasert praksis samt det å utforme problemstillinger var det mest utfordrende disse ukene. Samtidig ga studentene uttrykk for at det å veilede førsteårs sykepleierstudenter på simuleringsenheten var noe av det mest lærerike.

Som en avsluttende kommentar sa en av studentene i plenum: «Vi har blitt mer stolte og fått mer selvtillit som sykepleiere.»

\section{Entusiasme}

For lærerne som underviste i de ulike temaene, var det både en utfordring og en fordel med 16 studenter. Studentene viste seg å være engasjerte og virket svært motiverte for studiet og for muligheten til å oppnå autorisasjon som sykepleiere.

Studentenes entusiasme har vært en viktig inspirasjon for oss lærere og har gjort både teoriblokk og praksisuker innen eldreomsorg og psykisk helse meningsfulle. Utfordringer har imidlertid vært det skriftlige norske fagspråket samt å veilede dem inn i studentrollen, som er svært annerledes den de har erfart fra hjemlandet.

\section{三 «Utfordringer har vært det skriftlige norske fagspråket samt å veilede dem inn i studentrollen.»}

Etter teoriukene har studentene vært åtte uker i geriatripraksis på Lambertseter alders- og sykehjem i Oslo. Alle de sju sykepleierne ved sykehjemmet, som har besvart et spørreskjema om å veilede studenter $\mathrm{i}$ kompletterende utdanning, ønsker gjerne å veilede studenter igjen.

Alle sykepleierne er svært enige eller enige i at det er positivt å veilede studentene, og at de er faglig dyktige, gode bidragsytere og arbeidsomme. En av sykehjemmets leger beskrev studentene som svært reflekterte og dyktige til å observere.

\section{Avslutning}

Ut fra vår erfaring er det kompletterende studiet for sykepleiere utdannet utenfor EU et viktig bidrag både for den enkelte sykepleier, til det norske helsevesenet og til norsk sykepleierutdanning.

Våre råd til sykepleiere utdannet utenfor EU, er:

- Innfri kravene til norsk- og engelskkunnskaper og arbeid kontinuerlig med det norske språket, både skriftlig og muntlig.

- Sjekk din utdanning i Nokut med hensyn til omfang og nivå.

- Ved nivå på bachelorgrad: Send søknad om autorisasjon som sykepleier til Helsedirektoratet.

Gjennomfør kompletterende utdanning hvis Helsedirektoratet har foreslått dette i sitt vedtak. 


\section{Referanser}

1. Ugreninov E, Vedeler JS, Heggebø K, Gjevjon ER. Konsekvenser av sykepleiermangel i kommunene fra et pasient- og pårørendeperspektiv.

Oslo: Nova; 2017. Tilgjengelig fra: http://www.hioa.no/Om-HiOA/Senterfor-velferds-og-

arbeidslivsforskning/NOVA/Publikasjonar/Rapporter/2017/Konsekvenserav-sykepleiermangel-i-kommunene-fra-et-pasient-og-

paaroerendeperspektiv (nedlastet 12.03.2018).

2. Statistisk sentralbyrå. Betydelig underdekning av helsepersonell i 2035 [internett]. SSB; 19.04.2012 [sitert 22.03.2018]. Tilgjengelig fra: https://www.ssb.no/forskning/mikrookonomi/arbeidsmarked/betydeligunderdekning-av-helsepersonell-i-2035

3. Statistisk sentralbyrå. Helse- og sosialpersonell, 2015, 4. kvartal [internett]. SSB; 27.06.2016 [sitert 22.03.2018]. Tilgjengelig fra: https://www.ssb.no/arbeid-og-lonn/statistikker/hesospers/aar/2016-06-27

4. International Council of Nurses. The ICN code of ethics for nurses. Genève: ICN; 2012. Tilgjengelig fra: http://www.icn.ch/images/stories/documents/about/icncode_english.pdf (nedlastet 12.03.2018).

5. Helsedirektoratet. Brukerveiledning til WHOs globale kode for internasjonal rekruttering. Oslo: Helsedirektoratet; 2010. Tilgjengelig fra: https:/helsedirektoratet.no/Lists/Publikasjoner/Attachments/787/Brukerveiledningtil-whos-globale-kode-for-internasjonal-rekruttering-av-helsepersonell-IS0315.pdf (nedlastet 12.03.2018).

6. Meld. St. nr. 6 (2012-2013) En helhetlig integreringspolitikk. Mangfold og fellesskap. Oslo: Barne-, likestillings- og inkluderingsdepartementet; 2013.

7. Nordisk Ministerråd. Utdanning, arbeid og integrering i Norden. København: TemaNord; 2017.

8. Barne- og likestillingsdepartementet. Handlingsplan 2013-2016: Vi trenger innvandrernes kompetanse. Oslo: Likestillingsdepartementet; 2013.

9. Lov 2. juli $1999 \mathrm{nr}$. 64 om helsepersonell m.v. (helsepersonelloven). Tilgjengelig fra: https://lovdata.no/dokument/NL/lov/1999-07-02-64 (nedlastet 12.03.2018).

10. Dahl K, Dahlen KJ, Larsen K, Lohne V. Conscientious and proud but challenged as a stranger: immigrant nurses' perceptions and descriptions of the Norwegian healthcare system. Nordic Journal of Nursing Research.

2017;37(3):143-50.

11. Munkejord MC. Ulik praksis for godkjenning av utdanning. Sykepleien. 2017;6:44-47. Tilgjengelig fra: https://sykepleien.no/forskning/2017/05/migranters-erfaringer-medakkreditering-og-kvalifisering (nedlastet 13.03.2018).

12. Consulting RM. Utdanning, arbeid og integrering i Norden.

Delrapport 1 og 2. København: Nordisk ministerråd; 2017. 
13. Nokut. Godkjenning av utenlandsk kompetanse. Udatert. Tilgjengelig

fra: http://www.nokut.no/no/Fakta/Godkjenning-av-utenlandsk-kompetanse

(nedlastet 12.03.2018).

14. Kunnskapsdepartementet. Rammeplan for sykepleierutdanningen.

Oslo; 2008. Tilgjengelig fra:

https://www.regjeringen.no/globalassets/upload/kd/vedlegg/uh/rammeplaner/helse/rammeplan_sykepleierutdanning_08.pdf (nedlastet 12.03.2018). 